\title{
FANCA Gene
}

National Cancer Institute

\section{Source}

National Cancer Institute. FANCA Gene. NCI Thesaurus. Code C85995.

This gene may be involved in the mediation of DNA repair. 